NOTE

\title{
Caribbean yellow-band syndrome on Montastraea faveolata is not transmitted mechanically under field conditions
}

\author{
A. G. Jordán-Garza* , E. Jordán-Dahlgren \\ Instituto de Ciencias del Mar y Limnología, Universidad Nacional Autónoma de México, Ap. Postal 1152, \\ 77500 Cancún, Q. Roo, Mexico
}

\begin{abstract}
Caribbean yellow-band syndrome is a highly prevalent coral disease whose transmission mechanisms are unknown. Affected corals often show multifocal lesions of yellow-colored tissue. We tested the hypothesis that a mechanical vector was responsible for these multifocal lesions. Four presumably non-resistant colonies were experimentally manipulated. Tissue and microbial assemblages were taken from diseased tissue and injected into healthy-looking tissue. Seawater injections were used as controls. The manipulations created a small wound, as would be generated by a coral predator. After $1 \mathrm{mo}$, all lesions healed and showed no signs of disease. We therefore reject the hypothesis that a mechanical vector, acting in a similar way as our manipulations, was responsible for the multifocal lesions.
\end{abstract}

KEY WORDS: Coral · Disease $\cdot$ Caribbean yellow-band syndrome $\cdot$ Montastraea $\cdot$ Vector Resale or republication not permitted without written consent of the publisher

\section{INTRODUCTION}

Prevalence of infectious coral diseases has increased worldwide since the first observations more than 30 yr ago (Ward \& Lafferty 2004). This trend can be linked to changes in the environment that benefit potential pathogens and impair coral host immunity (Harvell et al. 2002, Muller et al. 2008). In spite of the increase in coral disease prevalence, few transmission models have been proposed. The alga Halimeda opuntia was suggested to be a reservoir and physical vector of Aurantimonas coralicida, the putative pathogen for white plague type II (Nugues et al. 2004), whereas the fire-worm Hermodice carunculata was shown to be a winter reservoir and vector of Vibrio shiloi, the pathogen for bacterial bleaching (Sussman et al. 2003, but see Leggat et al. 2007). Physical transmission has also been documented for the fungus Aspergillus sydowii, the causative agent of aspergillosis on sea fans (Jolles et al. 2002). In that case, floating fungus fomites, or direct contact of con- tiguous hosts, transmitted the disease. Williams \& Miller (2005) also showed that a form of white disease on the coral Acropora cervicornis was transmissible by direct contact with the coral-eating snail Coralliophila abbreviata. Finally, black-band disease was transmissible in aquaria when a wound or a corallivorous fish was present (Aeby \& Santavy 2006). Indirect evidence also suggests the role of fishes as possible vectors of 6 coral diseases from the Pacific Ocean (Raymundo et al. 2009).

Caribbean reefs contain 2 sets of coral species that comprise the main keystone reef-builders: Acropora palmata (and A. cervicornis) and species of the Montastraea annularis complex. These species have been heavily impacted by disease. White-band disease devastated acroporid populations around the Caribbean basin (Gladfelter 1982, Precht et al. 2002), while populations of the $M$. anuularis species complex are being severely affected by more than 8 different signs and syndromes described to date (Sutherland et al. 2004, Weil 2004). Among the various signs affecting 
Montastraea sp., the slow-progressing and lethal Caribbean yellow-band/blotch syndrome (CYB) is a great cause of concern because of its widespread mortality (Santavy et al. 1999, Jordán-Dahlgren et al. 2005, Bruckner \& Bruckner 2006). Despite its widespread nature and high prevalence, the cause of CYB is still debated and its mode of transmission remains unknown. The disease seems to affect coral endosymbionts, causing a reduction in their mitotic rate, which leads to coral death (Cervino et al. 2001, 2004). In laboratory experiments, Cervino et al. (2008) found that a consortium of Vibrio sp. strains isolated from CYBdiseased tissue produced disease signs when inoculated into healthy coral fragments. However, in situ transmission has never been documented. Furthermore, large $M$. faveolata colonies commonly have multi-focal (focus is used here to describe a central point or locus of an infection) lesions, as the result of new lesions appearing on different colony locations. These new lesions expand and eventually may coalesce with other lesions (Bruckner \& Bruckner 2006). However, it is unknown whether each lesion is a result of a new infection. We tested the hypothesis that CYB could be mechanically transmitted by simulating fish bites under field conditions.
Yellow-band manipulations. To test whether CYB could be mechanically transmitted, tissue from a yellow-band lesion was extracted with a syringe and then injected into apparently healthy areas of the same colonies from which the extract was obtained. For each experimental series, a new syringe was used to inject tissue and microbial assemblages $(\sim 2 \mathrm{ml})$ following Cervino et al. (2004). Tissue was taken from the middle of a yellow-band lesion and injected into adjacent, apparently healthy, tissue. A similar procedure was followed using surrounding seawater ( 2 ml) to control the experimental manipulations. Once the inoculum was injected, we purposefully destroyed 3 to 4 polyps with the tip of the syringe, creating lesions approximately $100 \mathrm{~mm}^{2}$, to mimic the effect of a small bite with only slight damage to the skeleton (Rotjan \& Lewis 2008). To guarantee no confusion in later recordings, nails were used as a benchmark to locate the inoculation foci (Fig. 1). Five injection series were done perpendicular to the coral edge under the benchmarks. The first injection was done closer to the colony edge $( \pm 10 \mathrm{~cm})$, and subsequent injections were aligned perpendicular to the edge and spaced $5 \mathrm{~cm}$ from each other, so that the last injection was $\pm 30 \mathrm{~cm}$ within the coral tissue (Fig. 1). If intra-colony variation existed,

\section{MATERIALS AND METHODS}

Study site and colony selection. The study was conducted on the back reef of Puerto Morelos, Yucatán, Mexico $\left(20^{\circ} 53.012^{\prime} \mathrm{N}, 86^{\circ} 50.913^{\prime} \mathrm{W}\right)$, a well developed reef with abundant massive Montastraea annularis and M. faveolata (Jordán-Dahlgren \& Rodríguez-Martínez 2003). In situ seawater temperature was measured with a submersible Stowaway Tidbit (TBI32, $0.3^{\circ} \mathrm{C}$ resolution) that was attached under a coral colony. The Tidbit was programmed to take measurements every hour.

Because some colonies may be resistant to the purported pathogen, we selected colonies which have had progressing multifocal yellow-band signs for several years (E. Jordán-Dahlgren pers. obs.). Knowing that the coral's immune system was unable to resist infections in the past, we assumed that those colonies would be susceptible to further infections (but see Reed et al. 2010). Four colonies of Montastraea faveolata were selected at 2 sites on the back reef of Puerto Morelos to be used for the inoculation experiments.

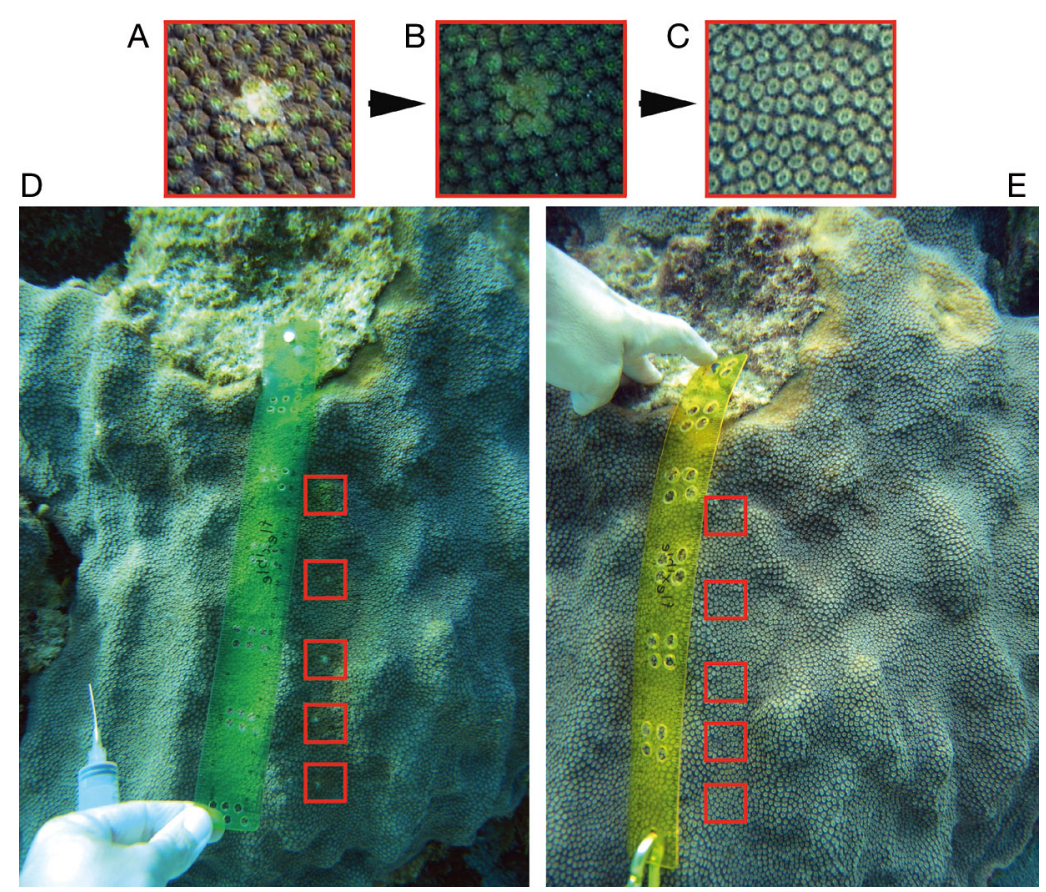

Fig. 1. Montastraea faveolata. Physically induced lesions on corals at Puerto Morelos, Mexico. (A) Recent lesion. (B) Lesion 1 mo later, showing weak yellowness. (C) Tissue after $5 \mathrm{mo}$; no lesion or signs are visible. (D) Every lesion of treatments and controls showed a yellow hue $1 \mathrm{~d}$ after manipulation (red squares). (E) After $5 \mathrm{mo}$, regeneration of the lesions was complete, and no signs of yellow-band disease were evident on any of the inflicted lesions (experimental or control) 
e.g. different zooxanthellae clades (Rowan \& Knowlton 1995) or allocation potential, then each injection, depending on its location within the colony, would be independent from other injections, but this was unknown. Six stainless-steel nails were placed on nonliving areas on each colony, 3 adjacent to CYB signs (experimental inoculations); the same was done on locations adjacent to apparently healthy tissue within the same corals (control inoculations). On each coral colony, 6 series (3 experimental and 3 control) were made, resulting in 15 experimental lesions and 15 control lesions per colony, for a total of 60 experimental and 60 control lesions on the 4 studied coral colonies.

The experiment began in September 2007 when seawater temperatures were at the annual maximum and pathogens were more likely to proliferate (Harvell et al. 2002). After the first series of inoculations, the colonies were examined every $2 \mathrm{~d}$ for $2 \mathrm{wk}$, then every month until the last survey in January 2008.

\section{RESULTS AND DISCUSSION}

The tissue surrounding the artificial lesions, both for CYB inoculations and controls, showed a yellow hue following the first manipulations. We discerned 3 color stages, in comparison to surrounding tissue: a strong yellowness, a weak yellowness and no signs at all (Fig. 2). The time to complete tissue regeneration was noted. No significant differences in the proportion of lesions with strong and weak yellowing between colonies, 2 wk after the start of the study, were noticed for controls $\left(\chi^{2}=0.63, \mathrm{df}=3, \mathrm{p}=0.89\right)$ or for CYB inocu$\operatorname{lum}\left(\chi^{2}=0.53, \mathrm{df}=3, \mathrm{p}=0.91\right)$. Data from all 4 colonies were pooled, and the median percentage of tissue with signs of CYB and the average absolute deviation of the total number of lesions were calculated for the first $2 \mathrm{wk}$ of observations and then every month until the end of the experiments (Fig. 2). The yellow hue decreased in intensity with time, until no signs were visible at all.

In situ mean $( \pm \mathrm{SD})$ seawater temperature recorded for September 2007 was $29.9 \pm 0.4^{\circ} \mathrm{C}(\mathrm{n}=720)$, which was within the $11 \mathrm{yr}$ average for this month $(29.3 \pm$ $0.5^{\circ} \mathrm{C}_{i}$ Rodríguez-Martínez et al. 2010). In laboratory conditions, inoculations have successfully transmitted signs of CYB on Montastraea sp. fragments at temperatures ranging from 28 to $31^{\circ} \mathrm{C}$ (Cervino et al. 2004, Weil et al. 2008). Therefore, we expected September water temperatures to be adequate for transmitting new infections at the study sites. Immediately after the manipulations, the tissue surrounding the lesions took on a yellowish hue for all treatment levels. Within $1 \mathrm{mo}$, the coral colonies had regenerated tissue and polyps on the experimental and control lesions, and a less intense yellow hue was still visible on the majority of the inflicted lesions. After $5 \mathrm{mo}$, regeneration was complete and there were no signs of yellow tissue on any of the injection foci (Fig. 2). No successful transmission of CYB signs and no difference in tissue regeneration were observed, between or within, the 4 coral colonies and treatment levels (experimental, controls) at the end of the 5 mo observational study. It seems evident that the change in color on the produced lesions

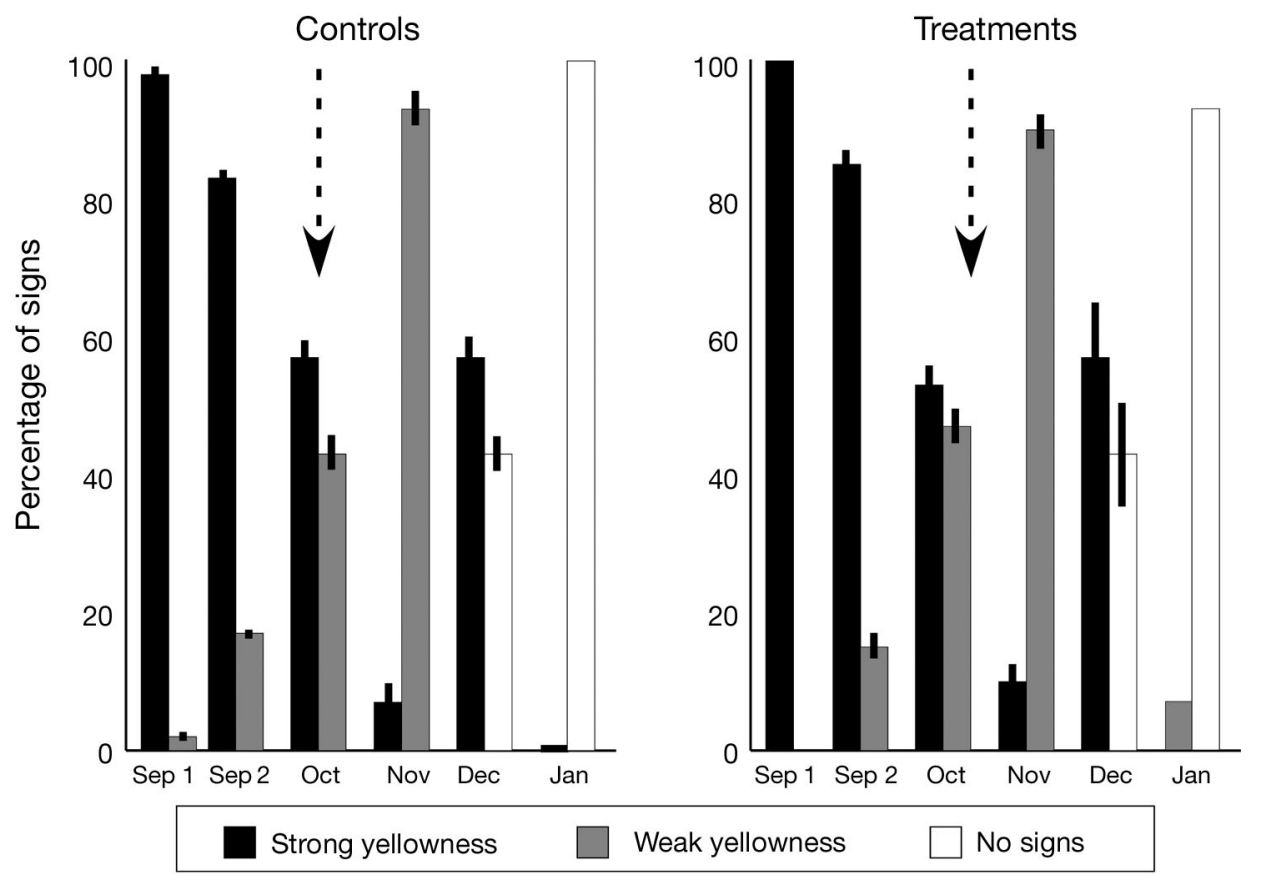

Fig. 2. Montastraea faveolata. Percent of experimentally induced lesions in corals with yellow-band syndrome and controls. Data expressed as median (bars) and median absolute deviation (solid lines) of the total number of lesions. Dotted arrows indicate almost complete tissue regeneration on the artificial lesion area. September 1 and 2 correspond to weekly observations during the first 2 consecutive weeks. Afterwards, a single observation per month was made $(\mathrm{n}=4$ coral colonies, $\mathrm{n}=$ 60 treatment lesions, $\mathrm{n}=60$ control lesions) 
reflected the healing process, rather than successful transmissions of CYB. Controls and experimental lesions recovered at a similar rate, and the time taken for the damaged polyps to regenerate was consistent with the period observed by Meesters et al. (1992) on healthy colonies of Montastraea sp. The experimental coral colonies in this study were chosen because they already had multifocal CYB signs, and thus it is known that they were unable to fight infection on several foci in the past. However, none of our manipulations resulted in new CYB lesions, and furthermore the colonies appeared to retain normal regenerative capacities on their apparently healthy tissue, independently of treatment (controls or CYB inoculations). We reject the hypothesis that a mechanical vector, acting similarly as our manipulations, would cause the multifocal lesions within a coral colony, under natural conditions.

Our findings also suggest a local effect of the disease, given the regeneration time observed. The diseased tissue of the colonies dies at relatively slow rates (A. G. Jordán-Garza pers. obs. in situ, also see rates in Cervino et al. 2001), but at the same time, the apparently healthy tissue of the experimental colonies showed a normal capacity to regenerate the small wounds (Meesters et al. 1992). In contrast, Weil et al. (2009) suggested that Montastraea sp. yellow-band diseased coral colonies reacted in a systemic manner, as these authors found an apparent, but not statistically significant, reduction in the reproductive effort of the healthy-looking tissues of diseased colonies. Diseased colonies may be allocating resources to preserve tissue integrity and prevent disease advancement (Mydlarz et al. 2009), resulting in an impairment in reproductive output. Alternatively, because reproduction in corals is linked to tissue surface area, it is also possible that partial mortality resulting from the disease progression indirectly affects their reproductive output (Soong \& Lang 1992). In accordance with trade-off theory, the energy used toward reproduction may impair the immune system (Sheldon \& Verhulst 1996). Our study did not control for the reproductive state of the experimental coral colonies, but our results suggest they maintained the ability to resist new infections, probably by the release of antibacterial materials after an induced wound, as shown by Geffen \& Rosenberg (2005).

It is important to examine the inoculation method used here, because it could be related to the lack of transmission. We produced a small wound with a single inoculation of microbial assemblages; this could be similar to a predator with high motility or an extensive territory, that would bite the colony a few times while swimming by, e.g. the spot-biting behavior of parrotfishes (Rotjan \& Lewis 2008). If the predators were territorial and with limited movement around a single coral colony, e.g. butterflyfishes (Reese 1989), then the probability that they repeatedly bite the same area within the colony would be higher; this could increase the pathogen dosage and may facilitate infection, if mechanical transmission is feasible at all. On the other hand, CYB on Montastraea faveolata may be transmitted by a biological vector, although so far only mechanical transmission has been successful under laboratory conditions, using inoculations directly extracted from CYB (Cervino et al. 2008). Experimental field manipulations attempting to transmit CYB signs have been unsuccessful (present study; E. Weil pers. comm.).

Presently, it remains unknown how CYB, and the multiple infections associated with this coral disease, are transmitted. Corals are modular organisms, it may be that intra-colony variation exists on the defense against diseases, as has been shown for plants (Pavia et al. 2002), and that environmental drivers could exacerbate or impair those defenses (Harvell 1986). Lesser et al. (2007) suggested that coral diseases are infections that appear after a stress has hampered the coral immune system. If this is so, compromised coral immunity may vary within a coral colony, and the multiple lesions of yellow-band might be dependent on this variability. However, it is not yet known if the purported causative agents of CYB are primary or opportunistic pathogens. Given the continuous emergence of diseases in corals (as in many other organisms), we can state that the rapidly degrading coral reef environment may be compromising all 3 major components of the holobiont immune system: the animal, the zooxanthellae, and the coral's microbial community. In such a situation, multiple mechanisms may exist for an infection to occur, and more experimental approaches are needed to understand how this disease spreads in nature.

Acknowledgements. We thank R. van Woesik and E. Muller for valuable editorial comments on our manuscript. We also thank R. E. Rodríguez-Martínez for help with field work and the 'Consejo Nacional de Ciencia y Tecnología,' which supported A.G.J.G. This work was part of the Coral Reef Targeted Research (CRTR) Program's Disease Working Group, supported by the Instituto de Ciencias del Mar y Limnología (Universidad Nacional Autónoma de México) and the Disease Working Group of the Coral Reef Targeted Research program.

\section{LITERATURE CITED}

Aeby GS, Santavy DL (2006) Factors affecting susceptibility of the coral Montastraea faveolata to black-band disease. Mar Ecol Prog Ser 318:103-110

Bruckner AW, Bruckner RJ (2006) The recent decline of Montastraea annularis (complex) coral populations in western Curaçao: a cause for concern? Rev Biol Trop 54:45-58 
Cervino J, Goreau TJ, Nagelkerken I, Smith GW, Hayes R (2001) Yellow band and dark spot syndromes in Caribbean corals: distribution, rate of spread, cytology, and effects on abundance and division rate of zooxanthellae. Hydrobiologia 460:53-63

Cervino JM, Hayes RL, Polson SW, Polson SC, Goreau TJ, Martinez RJ, Smith GW (2004) Relationship of Vibrio species infection and elevated temperatures to yellow blotch/ band disease in Caribbean corals. Appl Environ Microbiol 70:6855-6864

Cervino JM, Thompson FL, Gomez-Gil B, Lorence EA and others (2008) The Vibrio core group induces yellow band disease in Caribbean and Indo-Pacific reef-building corals. J Appl Microbiol 105:1658-1671

Geffen Y, Rosenberg E (2005) Stress-induced rapid release of antibacterials by scleractinian corals. Mar Biol 146: 931-935

Gladfelter WB (1982) White-band disease in Acropora palmata: implications for the structure and growth of shallow reefs. Bull Mar Sci 32:639-643

> Harvell CD (1986) The ecology and evolution of inducible defenses in a marine bryozoan: cues, costs, and consequences. Am Nat 128:810-823

Harvell CD, Mitchell CE, Ward JR, Altizer S, Dobson AP, Ostfeld RS, Samuel MD (2002) Climate warming and disease risks for terrestrial and marine biota. Science 296: 2158-2162

Jolles AE, Sullivan P, Alker AP, Harvell CD (2002) Disease transmission of aspergillosis in sea fans: inferring process from spatial pattern. Ecology 83:2373-2378

Jordán-Dahlgren E, Rodríguez-Martínez RE (2003) The Atlantic coral reefs of Mexico. In: Cortés J (Ed) Latin American coral reefs. Elsevier, Amsterdam, p 131-158

Jordán-Dahlgren E, Maldonado MA, Rodríguez-Martínez R (2005) Diseases and partial mortality in Montastraea annularis species complex in reefs with differing environmental conditions (NW Caribbean and Gulf of México). Dis Aquat Org 63:3-12

Leggat W, Ainsworth T, Bythell J, Dove S and others (2007) The hologenome theory disregards the coral holobiont. Nat Rev Microbiol 5. doi:10.1038/nrmicro1635-c1

Lesser MP, Bythell JC, Gates RD, Johnstone RW, HoeghGuldberg O (2007) Are infectious diseases really killing corals? Alternative interpretations of the experimental and ecological data. J Exp Mar Biol Ecol 346:36-44

Meesters EH, Bos A, Gast GJ (1992) Effects of sedimentation and lesion position on coral tissue regeneration. Proc 7th Int Coral Reef Symp, Guam 2:671-678

Muller EM, Rogers CS, Spitzack AS, van Woesik R (2008) Bleaching increases likelihood of disease on Acropora palmata (Lamarck) in Hawksnest Bay, St John, US Virgin Islands. Coral Reefs 27:191-195

Mydlarz LD, Couch CS, Weil E, Smith G, Harvell CD (2009) Immune defenses of healthy, bleached and diseased Montastraea faveolata during a natural bleaching event. Dis Aquat Org 87:67-78

Nugues MM, Smith GW, van Hooidonk RJ, Seabra MI, Bak RPM (2004) Algal contact as a trigger for coral disease.

Editorial responsibility: Garriet Smith,

Aiken, South Carolina, USA
Ecol Lett 7:919-923

Pavia H, Toth GB, Aberg P (2002) Optimal defense theory: elasticity analysis as a tool to predict intraplant variation in defenses. Ecology 83:891-897

Precht W, Bruckner A, Aronson R, Bruckner R (2002) Endangered acroporid corals of the Caribbean. Coral Reefs 21:41-42

Raymundo LJ, Halford AR, Maypa AP, Kerr AM (2009) Functionally diverse reef-fish communities ameliorate coral disease. Proc Natl Acad Sci USA 106:17067-17070

Reed KC, Muller EM, van Woesik R (2010) Coral immunology and resistance to disease. Dis Aquat Org 90:85-92

Reese ES (1989) Orientation behavior of butterflyfishes (family Chaetodontidae) on coral reefs: spatial learning of route specific landmarks and cognitive maps. Environ Biol Fishes 25:79-86

Rodríguez-Martínez RE, Ruíz-Rentería F, van Tussenbroek B, Barba-Santos G, Escalante-Mancera E, Jordán-Garza G, Jordán-Dahlgren E (2010) Environmental state and tendencies of the Puerto Morelos CARICOMP site, Mexico. Rev Biol Trop 58:23-43

Rotjan RD, Lewis SM (2008) Impact of coral predators on tropical reefs. Mar Ecol Prog Ser 367:73-91

Rowan R, Knowlton N (1995) Intraspecific diversity and ecological zonation in coral-algal symbiosis. Proc Natl Acad Sci USA 92:2850-2853

> Santavy DL, Peters EC, Quirolo C, Porter JW, Bianchi CN (1999) Yellow-blotch disease outbreak on reefs of the San Blas Islands, Panama. Coral Reefs 18:97

Sheldon BC, Verhulst S (1996) Ecological immunology: costly parasite defences and trade-offs in evolutionary ecology. Trends Ecol Evol 11:317-321

Soong K, Lang JC (1992) Reproductive integration in reef corals. Biol Bull (Woods Hole) 183:418-431

Sussman M, Loya Y, Fine M, Rosenberg E (2003) The marine fireworm Hermodice carunculata is a winter reservoir and spring-summer vector for the coral-bleaching pathogen Vibrio shiloi. Environ Microbiol 5:250-255

Sutherland KP, Porter JW, Torres C (2004) Disease and immunity in Caribbean and Indo-Pacific zooxanthellate corals. Mar Ecol Prog Ser 266:273-302

Ward JR, Lafferty KD (2004) The elusive baseline of marine disease: Are diseases in ocean ecosystems increasing? PLoS Biol 2:542-547

Weil E (2004) Coral reef diseases in the wider Caribbean. In: Rosenberg E, Loya Y (eds) Coral health and disease. Springer-Verlag, New York, NY, p 35-68

Weil E, Ritchie KB, Croquer A, Cunning JR, Smith GW (2008) Inoculation of Vibrio spp. onto Montastraea faveolata fragments to determine potential pathogenicity. Proc 11th Int Coral Reef Symp, Florida 1:202-205

> Weil E, Cróquer A, Urreiztieta I (2009) Yellow band disease compromises the reproductive output of the Caribbean reef-building coral Montastraea faveolata (Anthozoa, Scleractinia). Dis Aquat Org 87:45-55

Williams DE, Miller MW (2005) Coral disease outbreak: pattern, prevalence and transmission in Acropora cervicornis. Mar Ecol Prog Ser 301:119-128

Submitted: December 20, 2010; Accepted: April 8, 2011

Proofs received from author(s): July 7, 2011 